\title{
PROXY SERVER DAN MANAGEMENT BANDWIDTH JARINGAN KOMPUTER MENGGUNAKAN MIKROTIK RB952Ui5ac2nD (Studi Kasus MA Ishlahul Ikhwan Nahdlatul Wathan Mispalah Praya)
}

\author{
Disususn Oleh: \\ Wirabakti' $^{1}$, Khairul Imtihan ${ }^{2}$, Ahmad S. Pardiansyah ${ }^{3}$ \\ 1,Jurusan Teknik Informatika, 2,STMIK Lombok \\ 1wirabakti245@gmail.com, ${ }^{2}$ khairulimtihan31@gmail.com ${ }^{3}$ ahmad.pardiansyah84@gmail.com
}

\begin{abstract}
The condition of existing networks in Madrasah Aliyah Ishlahul Ikhwan Nahdlatul Wathan Mispalah Praya network managers currently facing several challenges related to the existing internet connection point is a limited bandwidth connection and not proportional to the number of existing users. Internet connection utilization through Local Area Network at study hours, ie from morning to night. This policy has an impact on their complaints from teachers, students and not optimal internet connection services available. In addition to the lack of LAN network security used. With such a solution it is necessary to reduce the impact of internet connection instability on the Madrasah Aliyah Ishlahul Ikhwan Nahdlatul Wathan Mispalah Praya network by adding Mikrotik RB952Ui5ac2nd that serves as a proxy server, and bandwidth management.

The purpose of this research is to improve LAN network security in Madrasah Aliyah Ishlahul Ikhwan Nahdlatul Wathan Mispalah Praya by adding mikrotik RB952Ui-5ac2nD, facilitate access to Internet by adding proxy server, and doing bandwidth distribution. Data collection method used is observation method, interview and literature study. From some of these methods will be analyzed network problems and create the required design, then test the new design results. The required equipment is Mikrotik RB952U-5ac2nD for proxy server and bandwidth management to generate blocking system design, increase internet access speed, and optimize bandwidth usage.
\end{abstract}

Keywords: Proxy Server, Bandwidth Management, Mikrotik RB952Ui-5ac2nD

Abstrak

Kondisi jaringan yang ada di Madrasah Aliyah Ishlahul Ikhwan Nahdlatul Wathan Mispalah Praya pengelola jaringan saat ini menghadapi beberapa tantangan terkait dengan titik koneksi internet yang ada adalah koneksi bandwidth yang terbatas dan tidak sebanding dengan jumlah pengguna yang ada. Koneksi internet pemanfaatan melalui Local Area Network pada jam belajar, yaitu dari pagi hingga malam. Kebijakan ini berdampak pada keluhan mereka dari guru, siswa dan tidak optimalnya layanan koneksi internet yang ada. Selain tidak adanya keamanan jaringan LAN yang digunakan. Dengan solusi seperti itu maka perlu untuk mengurangi dampak ketidakstabilan koneksi internet di jaringan Madrasah Aliyah Ishlahul Ikhwan Nahdlatul Wathan Mispalah Praya dengan menambahkan Mikrotik RB952Ui5ac2nd yang berfungsi sebagai proxy server, dan manajemen bandwidth.

Tujuan penelitian dilakukan untuk meningkatkan keamanan jaringan LAN di Madrasah Aliyah Ishlahul Ikhwan Nahdlatul Wathan Mispalah Praya dengan menambahkan mikrotik RB952Ui-5ac2nD, memudahkan akses ke Internet dengan menambahkan proxy server, dan melakukan distribusi bandwidth. Metode pengumpulan data yang digunakan adalah metode observasi, wawancara dan studi pustaka. Dari beberapa metode ini akan dilakukan analisis masalah jaringan dan membuat desain yang dibutuhkan, kemudian menguji hasil desain baru. Peralatan yang dibutuhkan adalah Mikrotik RB952U-5ac2nD untuk server proxy dan manajemen bandwidth untuk menghasilkan rancangan sistem blocking, meningkatkan kecepatan akses internet, serta mengoptimalkan penggunaan bandwidth

Kata Kunci : Proxy Server, Bandwidth Management, Mikrotik RB952Ui-5ac2nD

\section{Pendahuluan}

Didalam Perkembangan Teknologi, kebutuhan akses internet sangatlah tinggi. Bahkan saat ini, mungkin internet sudah dapat dikatakan sebagai kebutuhan primer baik itu dapat secara pribadi maupun untuk perusahaan. Namun untuk mendapatkan koneksi internet di negara ini masih butuh mengeluarkan biaya yang cukup besar untuk mendapatkan koneksi dan kecepatan yang baik (Devie Ryana, 2014). 
Proxy server sejalan dengan banyaknya perusahaan yang memanfaatkan teknologi informasi, salah satunya adalah streaming, jejaring sosial, ataupun chatting, sehingga bandwidth internet perusahaan besarnya tetap tidak akan mencukupi kebutuhan akan bandwidth internet. Karena itu, diperlukan suatu manajemen pemakaian teknologi informasi.

Madrasah Aliyah Ishlahul Ikhwan Nahdlatul Wathan Mispalah Praya adalah salah satu pondok pesantren dibidang keagamaan yang di Praya. Untuk mendukung proses belajar mengajar, Madrasah Aliyah Ishlahul Ikhwan Nahdlatul Wathan Mispalah Praya menyediakan infrasrtuktur jaringan sekolah yang dikelola oleh bagian pengelola, laboratorium computer dan fasilitas yang ada dapat diakses melalui jaringan Local Area Network.

Pengelola jaringan pada Madrasah Aliyah Ishlahul Ikhwan Nahdlatul Wathan Mispalah Praya menghadapi beberapa kendala terkait dengan jalur koneksi internet yang ada yaitu bandwidth koneksi yang ada terbatas dan sudah tidak sebanding dengan jumlah pengguna yang ada, selain itu pemanfaatan koneksi internet melalui jalur jaringan Local Area Network pada jam pembelajaran yaitu mulai pagi hingga sore. Kebijakan ini berdampak pada adanya keluhan dari guru dan siswa dan tidak optimalnya layanan koneksi internet yang ada.

Sebagai salah satu solusi untuk mengurangi dampak ketidakstabilan koneksi internet pada jaringan Madrasah Aliyah Ishlahul Ikhwan Nahdlatul Wathan Mispalah Praya adalah dengan menggunakan router mikrotik yang berfungsi sebagai proxy server, yang dapat memfilter situssitus yang terlarang (Adult Content) dan mangement bandwidth menggunakan Mikrotik RB95952Ui-5ac2nD. Tujuan dari penelitian ini adalah menerapkan pengendalian dan keamanan penggunaan, membatasi akses ke suatu website, seperti memfilter situs porno dan memperlancarkan akses dan mengatur kecepatan bandwidth.

\section{Tinjuan Pustaka}

Andy Rachman and M. Aminullah, (2013) dalam penelitinya "Rancang Bangun Proxy Server Dan Analisis Pemakaian Internet Dengan Menggunakan Sarg" menyatakan proxy server saat ini mulai banyak dimanfaatkan perusahaanperusahaan di Indonesia. Pemakaian proxy server sejalan dengan banyaknya perusahaan yang memanfaatkan teknologi informasi, salah satunya adalah internet. Penggunaan internet di perusahaan banyak yang digunakan untuk kegiatan permainan online, video streaming, jejaring sosial, ataupun chatting, sehingga bandwidth internet perusahaan seberapapun besarnya tetap tidak akan mencukupi kebutuhan akan bandwidth internet. Oleh karena itu, diperlukan suatu manajemen pemakaian teknologi informasi. Proxy server merupakan salah satu solusi yang dapat digunakan, dimana dengan proxy server pihak manajemen perusahaan akan dapat membatasi pemakaian bandwith internet, pengaturan penggunaan internet dan mengurangi serangan virus, worm, spyware dan DDOS (Distributed Denial of Service). Pembuat laporan pemakaian internet, dan situs yang dikunjungi pengguna sangat sulit dilakukan dan membutuhkan waktu yang sangat lama. SARG merupakan salah satu solusi yang dapat dimanfaatkan oleh perusahaan dalam membantu manajemen dalam melakukan alokasi bandwidth dan mengatur penggunaan internet dengan cara yang sangat mudah dan cepat. Dengan pemanfaatan SARG, pengaturan bandwith, penggunaan internet dan pembuatan laporan pemakaian internet dapat dilakukan $80 \%$ lebih cepat dibandingkan cara manual.

Dani Kusuma Hermawan, dkk (2012) dalam penelitinya "Implementasi Bandwith Management Captive Portal Pada Jaringan Wireless Di PENS-ITS" menyatakan bahwa perkembangan teknologi informasi yang semakin pesat, mengubah sistem konvensional menjadi modern, terutama dengan adanya internet. Internet memberikan kontribusi yang demikian besar bagi masyarakat, perusahaan atau industri dan pemerintahan. Kebutuhan akan internet sudah dirasakan oleh masyarakat, hal ini terbukti dengan banyaknya fasilitas tempat umum seperti café, Mall, Kampus, Perkantoran dan sebagainya yang menyediakan fasilitas internet atau hotspot area. Pada tugas akhir ini di buat mekanisme keamanan built-in diperalatan WiFi 802.11.x untuk mengontrol siapa saja yang dapat berasosiasi ke Access Point (AP) . Penggunaan captive portal agar AP bekerja tanpa seting konfigurasi, sehingga tidak membebani kerja dari AP itu sendiri. AP bekerja pada mode bridge (bukan router) dan tersambung ke komputer server yang sudah terkonfigurasi sebagai router linux. Router linux berfungsi sebagai gateway penghubung antara jaringan lokal dengan jaringan internet. Agar lebih maksimal captive portal sebaiknya di tambahkan proxy server.

Imam Riadi, (2011) dalam penelitianya "Optimalisasi Keamanan Jaringan Menggunakan Pemfilteran Aplikasi Berbasis Mikrotik" menyatakan bahwa Pengguna jaringan komputer harus mengeluarkan investasi yang tidak sedikit untuk mengakses Internet. Internet telah memberikan pengaruh yang sangat besar pada penyebaran informasi, sehingga semakin banyak orang yang mengakses data melalui Internet. 
Permasalahan tersebut dapat diatasi menggunakan MikroTik sebagai pengatur lalu lintas data Internet serta melakukan pemfilteran beberapa aplikasi yang dapat mengganggu konektifitas jaringan komputer sesuai dengan aturan yang telah ditetapkan. Penelitian ini dilakukan menggunakan beberapa tahapan antara lain : analisis proses untuk menentukan alur lalulintas yang melewati proses pemfilteran menggunakan firewall, desain untuk mendapatkan cara yang paling efektif dan efisien mengimplementasikan router, implementasi serta pengujian yang dilakukan dengan metode stress test. Berdasarkan penelitian yang telah dilakukan aplikasi router menggunakan MikroTik yang di hasilkan dapat memenuhi kebutuhan sistem khususnya dalam melakukan pemfilteran aplikasi sesuai dengan kebutuhan pengguna.

\section{Metodologi Penelitian}

Metode perancangan proxy server dan management bandwidth menggunakan Mikrotik RB952Ui-5ac2nD pada Madrasah Aliyah Nahdlatul Wthan Mispalah Praya adalah Network Development Life Cycle (NDLC), sedangkan metode pengumpulan data menggunakan metode observasi, wawancara dan studi pustaka, untuk metode analisis menggunakan metode PIECES (Performance Information Economy Control Effeciency Service dengan tujuan menganalisa atau memperbaiki sistem yang sedang berjalan.

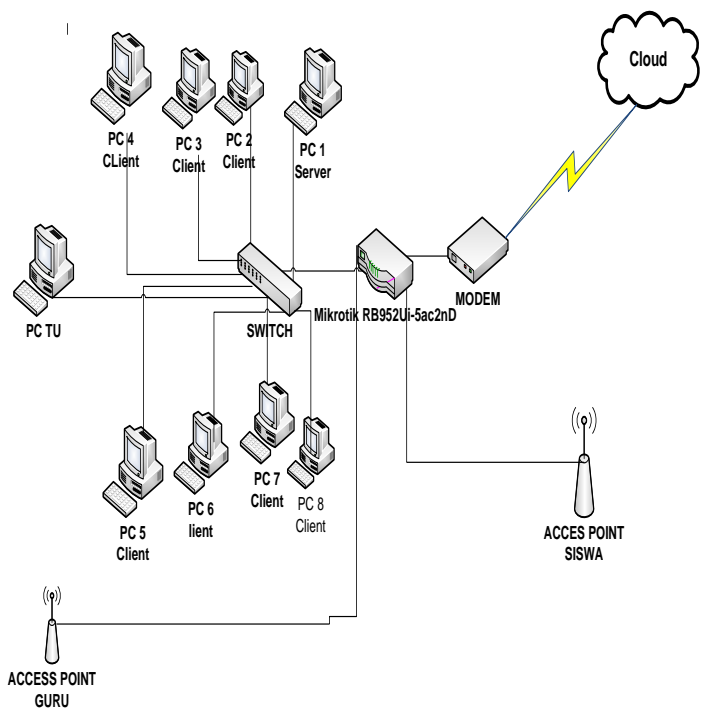

Gambar 3.1 Diagram jaringan yang di rencanakan

\section{Hasil dan Pembahasan}

4.1 Konfigurasi Web Proxy

Konfigurasi Web Proxy dengan memilih fitur IP $>$ Web Proxy
Terlihat tampilan web proxy settings, dimana tampilan ini melakukan konfigurasi dan kemudian klik acces untuk melanjutkan.

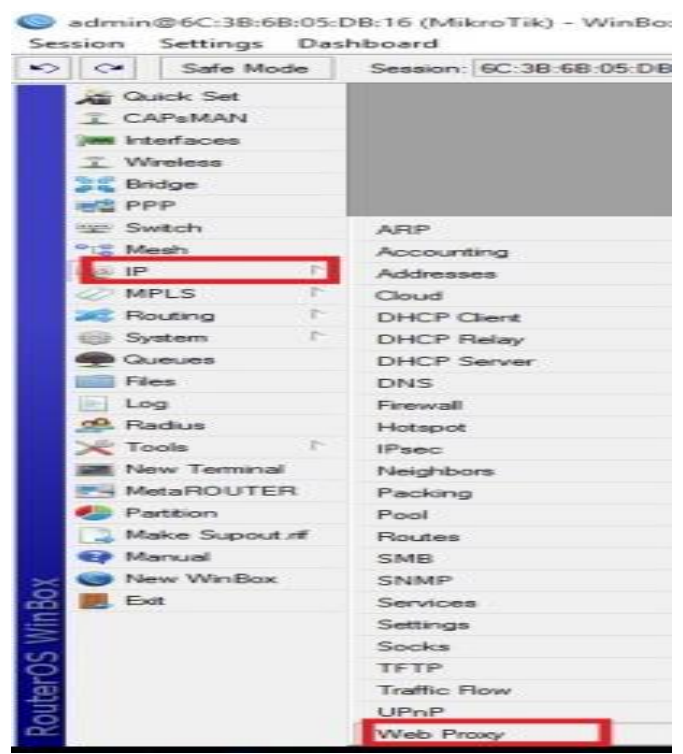

Gambar 4.1 Menu Web Proxy

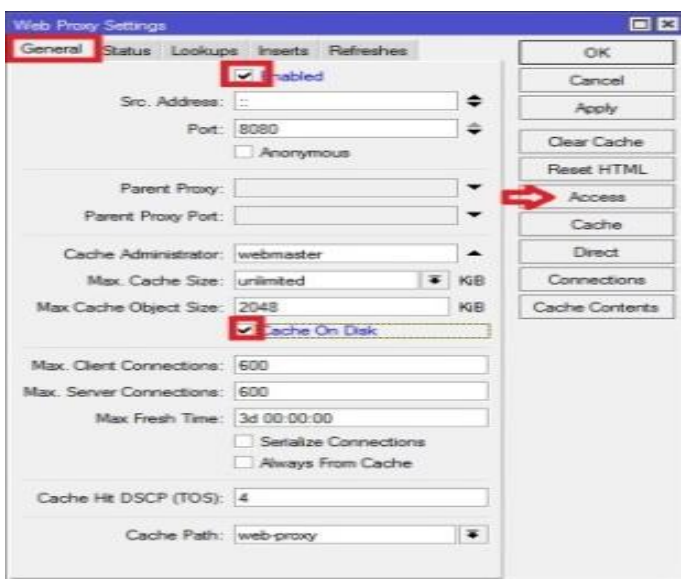

Gambar 4.2 Tampilan Web Proxy Settings

Setelah selesai melakukan konfigurasi pada web proxy, akan terlihat tampilan baru, dengan tab web proxy acces. Untuk melakukan konfigurasi pilih tab add (+)

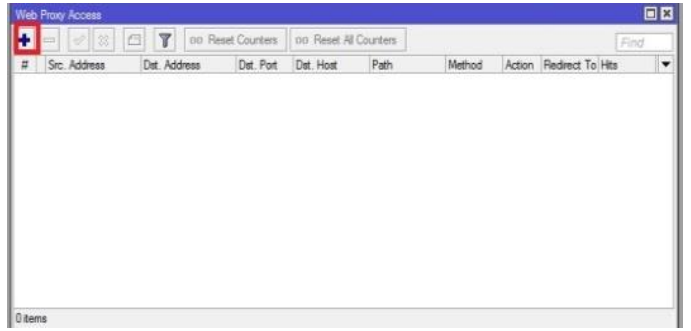

Gambar 4.3 Web Proxy Acces 
Terlihat tampilan dengan nama New Web Proxy Rule, selanjutnya mengisi perintah konfigurasi

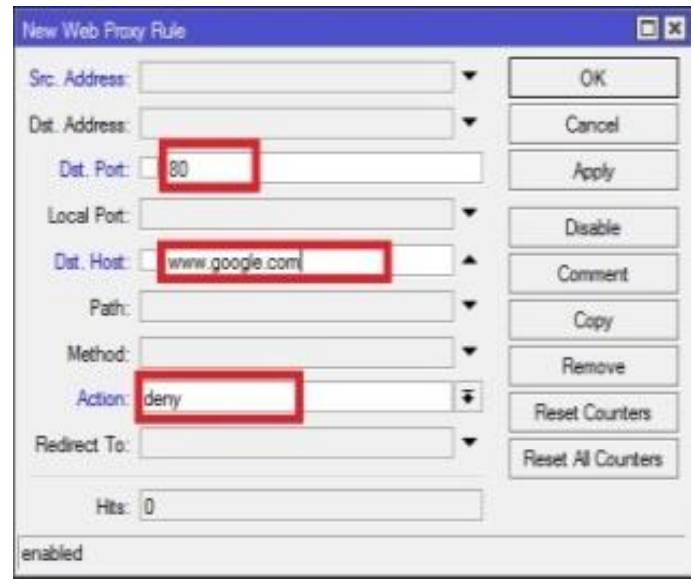

Gambar 4.4 New Web Proxy Rule

Akan terlihat daftar website yang diblokir, salah satu contohnya website yang di blokir www.playboy.com www.google.com

\begin{tabular}{|c|c|c|c|c|c|}
\hline Wat hay lows & & & & & \\
\hline $1=1 \times 0700 \mathrm{R}$ & Contes & oo Peset A Courte & & & \\
\hline 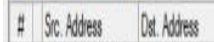 & Ad Pot & Cat how Pat & Nethow & 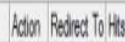 & \\
\hline $001921108100 \ldots$ & & & & dow & 0 \\
\hline 1000000 & & & & deny & 6 \\
\hline $201921688100 \%$ & & so & & den & 0 \\
\hline $301821680100 \%$ & & minploboy.... & & deny & 0 \\
\hline $40192,168100 \%$ & & 'porn' & & deny & 0 \\
\hline 50 & $D$ & ing govole. & & $\operatorname{den}$ & 0 \\
\hline
\end{tabular}

Gambar 4.5 Daftar Website di blokir

\subsection{Konfigurasi Management Bandwidt}

Pada fitur Mikrotik pilih fitur Queues List dan terlihat tampilan Queues List

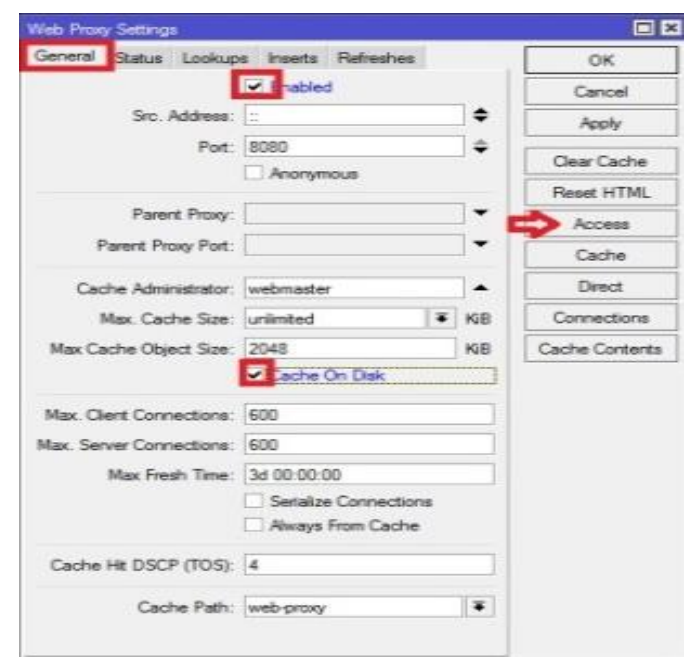

Gambar 4.6 Tampilan Queues List
Selanjutnya pilih add(+) untuk melakukan konfigurasi

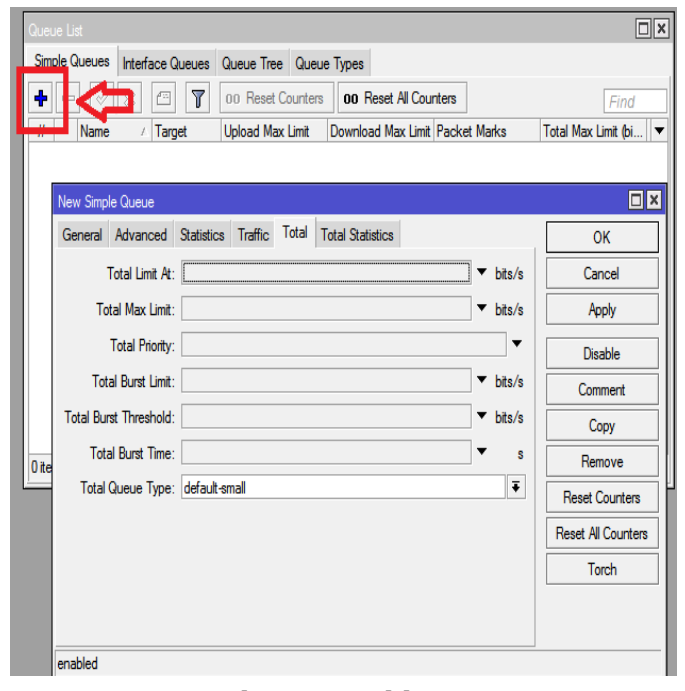

Gambar 4.7 Add Queues

Tampilan New Simple Queues Pada acces point siswa isi name siswa, target max limit upload dan download

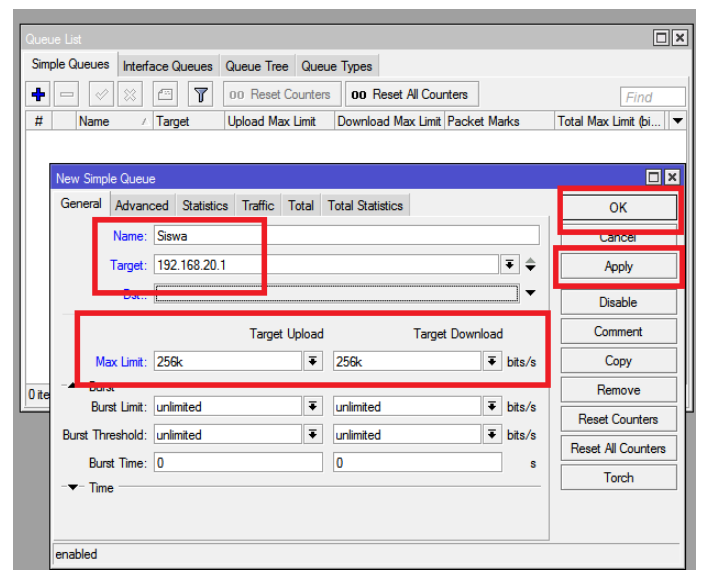

Gambar 4.8 Add New Simple Queue

Selanjutnya konfigurasi pada acces point Guru

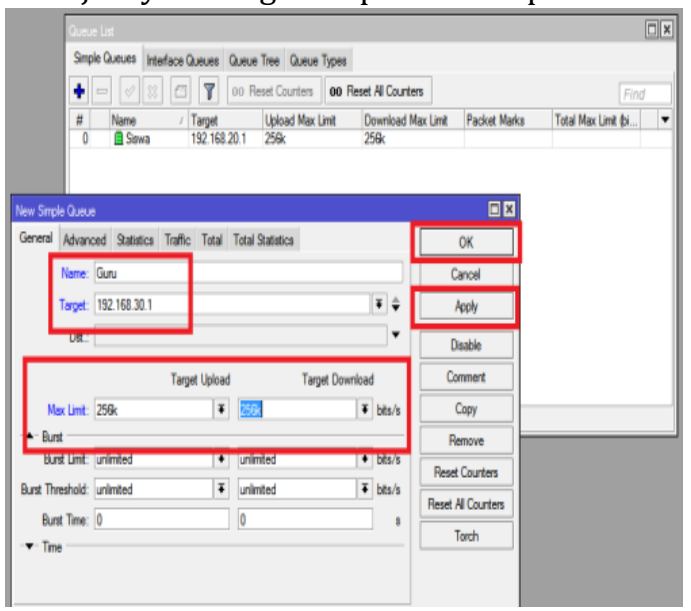

Gambar 4.9 Management acces point 


\subsection{Hasil Uji Coba}

Hasil pengujian proxy server pada browser dengan pemberitahuan Error: Forbidden

(4) (1) wnw playboy.com

ERROR: Forbidden

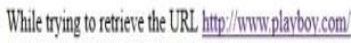

- Access Denied

Your cache administrator is mispalahprava Q amal com

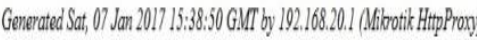

Gambar 4.10 Hasil Pengujian Dengan Browser

Acces Point Siswa dan Guru sudah di konfigurasi pada management bandwidth akan terlihat tampilan yang sudah ditambahkan.

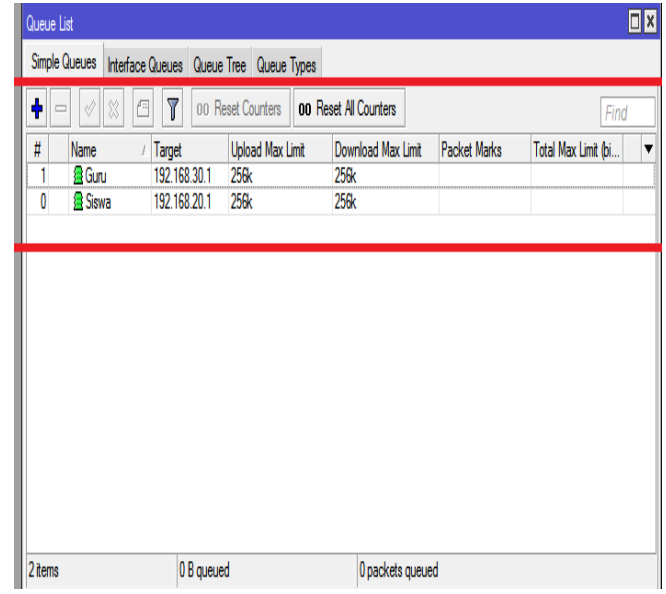

Gambar 4.11 Hasil management acces point

Pada hasil uji coba peneliti pada jaringan baru peneliti mendapatkan beberapa hasil analisis diantaranya.

1. Web Proxy

a. Web Proxy yang diterapkan pada perancangan jaringan MA Ishlahul Ikhwan Nahdlatul Wathan Mispalah Praya situs-situs tertentu yang membatasi client mengakses internet

b. Penerapan Web Proxy sudah tertanam pada konfigurasi routerboard yang digunakan RB952Ui-5ac2nD.

2. Management Bandwidth

a. Dengan management bandwidth semua client akan terbatasi dari segi upload dan download. b. Setiap client sudah memiliki kapasitas upload dan download yang sudah dibatasi

c. Client satu dengan client yang lain tidak dapat mengambil kapasitas yang lebih dari kapasitas yang sudah ditentukan.

\section{Kesimpulan dan saran \\ 5.1 Kesimpulan}

Dari uraian pada bab-bab yang telah dibahas sebelumnya, penulis dapat memperoleh kesimpulan sebgai berikut:

1. Penerapan pengendalian dan keamanan pengguna internet pada MA Ishlahul Ikhwan Nahdlatul Wathan Mispalah Praya dapat diterapkan, dan ketika user mengetikkan url addres maka proxy server melakukan pemfilteran situs-situs yang terlarang (Adult Content).

2. Dengan adanya pembagian bandwidth dapat dilakukan berdasarkan IP dari masingmasing Acces Point dan interface yang terhubung ke Mikrotik RB952Ui-5ac2nD, sehingga mendapatkan bandwidth untuk target upload 256k dan target download 256k.

3. Kestabilan dan kecepatan transfer data cendrung sama, yaitu dengan bandwidth, tareget upload 256k, target download 256k.

\subsection{Saran}

1. Dibutuhkan administrator jaringan yang bertugas untuk mengontrol sistem jaringan yang berjalan

2. Untuk peneliti selanjutnya, diperlukan pengembangan dengan memanfaatkan aplikasi yang berbasis open source agar dapat meminimalisir penggunaan aplikasi yang bajakan serta dapat memanilisir pengeluaran biaya yang besar untuk menerapkan proxy server.

3. Untuk peneliti selanjutnya, dapat mengubah penggunaan queues jenis simple queue ke jenis queues tree

4. Untuk peneliti selanjutnya, dibutuhkan pengklasifikasian dan pengurutan terhadap paket data dari prioritas tertinggi sampai terendah sesuai dengan karakteristik dari paket data.

\section{Daftar Pustaka:}

Devie Suchendra dan Aji Diyantori (2013) "Penerapan Squid Proxy Server dan Efisiensi Bandwidth menggunakan Mikrotik Router Pada lingkungan Perusahaan"http://ejournal.lpkia.ac.id/file s/students/essays/journals/233 .pdf 
Hermawan, Dani Kusuma, et al. "Implementasi Bandwith Management Captive Portal Pada Jaringan Wireless Di Pens ITS." Politeknik Electronika Negeri Surabaya (2012).

Riadi, Imam. "Optimalisasi Keamanan Jaringan Menggunakan Pemfilteran Aplikasi Berbasis Mikrotik." Jurnal Sistem Informasi Universitas Ahmad Dahlan, Yogyakarta. http://is. uad. ac. id/jusi (2011).

Rozak, Abdul, and Ahmad Susan Pardiansyah. "Perancangan Jaringan Virtual Metametarouter." Jurnal Manajemen Informatika dan Sistem Informasi 1.1 (2018): 17-23.

Rachman, Andy, and M. Aminullah. "RANCANG BANGUN PROXY SERVER DAN ANALISIS PEMAKAIAN INTERNET DENGAN MENGGUNAKAN SARG (STUDI KASUS DI BMKG JUANDA SURABAYA)." Jurnal IPTEK Vol 17.1 (2013).
Kalaena, Lalu Supriadi, and Wire Bagye. "Implementasi Network Attached Storage (NAS) Menggunakan Freenas Pada STMIK Lombok." Jurnal Manajemen Informatika dan Sistem Informasi 1.1 (2018): 6-10.

Susilawati, Sita, and Maulana Ashari. "Perancangan Jaringan Closed Circuit Television (CCTV) Berbasis Online Sebagai Monitoring Pada SDN 4 Praya." Jurnal Manajemen Informatika dan Sistem Informasi 1.1 (2018): 11-16.

Zaen, M. Taufan Asri, Sunaryo Sunaryo, and Wijono Wijono. "Sistem Pendukung Keputusan untuk Investasi Perumahan Area Malang Menggunakan P Algoritma Bayesian." Jurnal EECCIS 8.1 (2014): 13-18.

Hairul Fahmi "Efektifitas Wireless Lan Berbasis 802.11 b/g Sebagai Solusi Jaringan Kampus (Studi Kasus: Sekolah Tinggi Agama Hindu (STAHN) Gde Pudja Mataram." IJNSIndonesian Journal on Networking and Security 4.4 (2015). 